\title{
PERSEPSI NILAI PELANGGAN MEMEDIASI PENGARUH KEPERCAYAAN MEREK DAN KUALITAS LAYANAN TERHADAP LOYALITAS PELANGGAN BERBELANJA ONLINE
}

\author{
Dicka Puspita Ayu ${ }^{1}$ \\ Eka Sulistyawati ${ }^{2}$
}
${ }^{1,2}$ Fakultas Ekonomi dan Bisnis Universitas Udayana (Unud), Bali, Indonesia e-mail: dickapuspitaayu@ gmail.com

\begin{abstract}
ABSTRAK
Tujuan penelitian ini ialah peran persepsi nilai pelanggan memediasi kepercayaan merk dan kualitas layanan pada loyalitas pelanggan berbelanja online (Studi kasus pada Zalora Online shop). Penelitian ini dilakukan di media Zalora Online shop dengan teknik analisis data path analisa. Jumlah sampel yang didapat dengan menggunakan metode non probability sampling ialah sebanyak 150 responden. Berdasarkan hasil analisis dapat diketahui Kepercayaan merk berpengaruh positif signifikan terhadap loyalitas pelanggan. Kualitas layanan berpengaruh positif signifikan terhadap loyalitas pelanggan. Kepercayaan merk berpengaruh positif signifikan terhadap persepsi nilai pelanggan. Kualitas layanan berpengaruh positif signifikan terhadap persepsi nilai pelanggan. Persepsi nilai pelanggan berpengaruh positif signifikan terhadap loyalitas pelanggan. Persepsi nilai pelanggan memediasi pengaruh positif kepercayaan merk dan kualitas layanan terhadap loyalitas pelanggan berbelanja di Zalora Online shop.
\end{abstract}

Kata kunci : nilai pelanggan, kepercayaan merk, kualitas layanan, loyalitas pelanggan

\begin{abstract}
The purpose of this study is the role of customer value perception mediate brand trust and quality of service on customer loyalty online shopping (case study on Zalora Online shop). This research was conducted in Zalora Online shop with analytical data path analysis technique. The number of samples obtained by using non-probability sampling method is 150 respondents.Based on the results of the analysis can be known brand trust has a significant positive effect on customer loyalty. Quality of service has a significant positive effect on customer loyalty. Brand trust has a significant positive effect on the perception of customer value. Quality of service has a significant positive effect on the perception of customer value. The perception of customer value has a significant positive effect on customer loyalty. Customer value perceptions mediate the positive impact of brand trust and service quality on customer loyalty shopping at Zalora Online shop.
\end{abstract}

Keywords: customer value, brand trust, service quality, customer loyalty 
Dicka Puspita Ayu, Persepsi Nilai Pelanggan Memediasi Pengaruh...

\section{PENDAHULUAN}

Perkembangan internet dan jejaring sosial tidak hanya berfungsi sebagai media informasi dan media komunikasi saja namun juga sebagai tempat jual beli. Teknologi saat ini jauh lebih canggih dan terus berkembang dibanding dengan beberapa tahun lalu. Perkembangan teknologi tersebut dapat dirasakan didalam berbagai bidang mulai dari transportasi, komunikasi elektronik bahkan di dunia maya (Huang et al., 2011). Perkembangan teknologi ini terjadi seiring kemajuan gaya hidup masyarakat yang ikut berubah, salah satu yang paling mencolok dari perkembangan teknologi tersebut adalah gadget dan kecenderungan beraktivitas di dunia maya seperti berbelanja secara online atau lebih sering disebut dengan online shopping (Shahroudi et al., 2015).

Toko online pun kini semakin banyak dan berkembang, konsumen saat ini berbelanja tidak harus lagi dilakukan dengan bertemu penjual langsung di suatu tempat. Konsumen lebih mudah mencari dan memilih barang sesuai keperluan yang akan dibeli. Konsumen saat ini lebih menyukai semua hal yang berbau praktis dan otomatis untuk menjalankan kelangsungan hidupnya termasuk dalam hal menjalankan transaksi jual beli (Hermawan, 2009:112).

Online shopping atau belanja online adalah salah satu cara berbelanja yang sedang marak digunakan dalam transaksi jual beli. Online shopping juga merupakan bentuk jual beli melalui alat komunikasi elektronik atau media sosial di mana pembeli tidak perlu bersusah payah datang ke toko untuk melihat dan membeli apa yang konsumen butuhkan, karena dengan adanya online shopping konsumen hanya melihat barang yang diinginkan melalui media sosial kemudian 
memesan barang pilihan dan mentransfer uangnya lalu barang dikirim oleh onlineshop dan sampai kerumah. Online shop merupakan bentuk perubahan yang di sajikan oleh internet dari segi inovasi dalam berbelanja. Online shop pada setiap kesempatan menjadi perbincangan oleh sebagian kalangan masyarakat. Online shop memberikan berbagai kemudahan dalam proses transaksinya.

Media sosial merupakan salah satu fasilitas teknologi yang dijadikan sebagai "darah daging"masyarakat. Layanan jejaring sosial semacam itu rutin diakses oleh ratusan ribu atau bahkan jutaan masyarakat pengguna internet dari seluruh dunia. Fakta menunjukkan ternyata jumlah pengguna situs media sosial dan blog tidak hanya bertambah tiap tahunnya. Semakin besarnya penetrasi koneksi internet pemanfaatan layanan media sosial tersebut tidak dapat dipungkiri turut memberi andil terhadap perubahan atau evolusi terhadap bagaimana cara manusia berinteraksi satu sama lain yang menimbulkan 'ketergantungan sosial' terhadap layanan tersebut. Perbedaan media komunikasi juga akan mempengaruhi karakteristik komunikasi dan audiens yang terlibat di dalamnya. Komunikasi menggunakan situs media sosial juga memiliki karakteristik dalam proses komunikasi maupun audiennya. (edwi, 2011)

Perkembangan penggunaan internet saat ini mendorong adanya suatu potensi besar terciptanya online shopping. Online shoping telah menjadi fenomena pada saat ini karena dinilai lebih praktis, dari total pengguna internet, sekitar 36 juta pengguna internet yang melakukan belanja online (Hermawan, 2009:65). Internet mengalami perkembangan yang cukup pesat di tahun 1990-an. Salah satu pemicunya adalah ditemukan www (World Wide Web) yang mudah 
Dicka Puspita Ayu, Persepsi Nilai Pelanggan Memediasi Pengaruh...

digunakan dan aplikatif sifatnya bagi pengguna. Konsumen yang berpengalaman dengan teknologi merupakan bagian pasar potensial di internet bagi online shopping, biasanya pengguna adalah individu yang menyisihkan waktunya untuk e-mail, melakukan browsing serta melakukan berbagai pencarian lain seperti halnya untuk kepentingan pendidikan dan bisnis seperti yang diuraikan oleh (Sutedjo, 2006). Penelitian tentang belanja konsumen menyatakan bahwa browsing dapat membantu konsumen memenuhi kebutuhan mereka seperti menemukan sebuah produk, mendapatkan informasi, atau menjadi terbiasa dengan tata letak toko (Xia, 2010).

Menurut Huang et al. (2011) mayoritas pengguna internet di Indonesia pernah melakukan pembelanjaan secara online, sebanyak 57 persen dari total pengguna internet di Indonesia melakukan belanja online (online shopping). Oleh sebab itu peluang untuk menjalankan bisnis online semakin terbuka bagi pelaku bisnis di Indonesia. Pengguna alat elektronik (e-commerce) yang sedang marak saat ini memunculkan peluang bisnis baru yaitu penjualan secara elektronik yang menjadi alternatif dalam online shopping. Perdagangan elektronik (e-commerce) dimana perusahaan atau situs online menawarkan untuk melakukan transaksi atau memudahkan penjualan produk dan jasa online. E-marketing menggambarkan perusahaan berusaha untuk menginformasikan kepada pembeli, mengkomunikasikan, mempromosikan, dan menjual produk dan jasanya lewat internet (Kotler, 2012:153).

Studi yang dilakukan oleh Turley dan Milliman (2000); Arnold dan Reynolds(2003); Beneke et al. (2011) menjelaskan bahwa suasana, layanan dan 
kenyamanan menjadi pertimbangan pelanggan berbelanja offline, demikian juga dalam belanja online dibutuhkan adanya kenyamanan layanan, kepercayaan pelayanan yang baik mampu meningkatkan daya saing (Cronin et al., 2000). Semakin kompetitifnya persaingan bisnis berarti semakin penting memperhatikan loyalitas pelanggan. Loyalitas pelanggan merupakan salah satu kunci keberhasilan suatu usaha (Kotler dan Kevin Lane, 2008). Hal ini dikarenakan dengan memuaskan pelanggan, organisasi dapat meningkatkan keuntungannya dan mendapatkan pangsa pasar yang lebih luas.

Zalora adalah toko online fashion dan kecantikan yang menawarkan koleksi pakaian, aksesoris, sepatu dan produk kecantikan untuk pria dan wanita. Berpusat di Singapura, Zalora juga terdapat di Hong Kong, Singapura, Indonesia, Filipina, Thailand, Vietnam, Malaysia dan Brunei. Zalora sebagai online fashion destinasi terbesar di Asia Tenggara, didirikan pada awal tahun 2012. Pelanggan Zalora dapat menikmati kemudahan 30 hari gratis pengembalian, pengiriman gratis, pengiriman tercepat selama 1-3 hari kerja dan beberapa metode pembayaran termasuk COD (Cash On Delivery).

Keuntungan konsumen berbelanja di Zalora dengan kelebihan yang dapat dilihat dengan kemudahan untuk diakses melalui HP dengan tampilannya yang menarik. Produk dapat dikembalikan jika tidak puas dengan barang yang sudah di pesan dan di beli dengan syarat dan ketentuan yang berlaku. Gratis ke seluruh Indonesia tanpa minimum untuk Jabodetabek, untuk pulau Jawa, Bali, Sumatera dan Kalimantan, akan dikenakan biaya pengiriman jika pembelian di bawah Rp 200,000. Wilayah Indonesia Timur dan Nusa Tenggara, akan dikenakan biaya 
pengiriman jika pembelian di bawah Rp 300,000. Selain kelebihan Zalora juga memiliki beberapa ke kurangan dimana Websitenya semakain berat, kurang begitu mengupdate yang terbaru sehingga konsumen kurang begitu puas dengan layanan dan apa yang sudah dibeli dengan yang ditawarkan oleh Zalora.

Layanan menjadi sangat penting bagi pelanggan, disampaikan dengan tanggap, sigap, ramah dan cepat. Zalora memberikan pelayanan, menimbulkan rasa senang dan memberi nilai lebih menjadikan pelanggan merasa puas. Studi yang dilakukan oleh Parasuraman et al. (1988), menyatakan bahwa kualitas pelayanan yang baik mempunyai dampak signifikan terhadap loyalitas pelanggan, oleh karena itu pelayanan yang baik menjadi tantangan bagi organisasi dalam menghadapi pesaing dan mempertahankan pangsa pasar. Organisasi berusaha memberikan pelayanan yang menyenangkan dan dengan cara-cara tersebut diharapkan dapat meningkatkan loyalitas pelanggan. Cara-cara seperti itu juga diterapkan untuk memuaskan pelanggan.

Konsumen menganggap belanja online lebih berisiko daripada berbelanja offline, hal tersebut karena berbelanja secara offline dapat memberikan loyalitas pembelian fisik di mana pelanggan dapat melihat, merasakan dan menyentuh produk sebelum pembelian dilakukan (Heijden et al., 2003).Membangun kepercayaan dan mengelola risiko pada transaksi online yang bertujuan untuk meningkatkan penjualan menjadi sangat penting. Risiko transaksi online dan kepercayaan merupakan keterbatasan yang berpengaruh pada nilai yang dirasakan dan mendorong niat pembelian online dan berdampak pada loyalitas pelanggan. 
Selain tantangan ini, keamanan, penipuan, dan risiko kerugian juga dikenal sebagai kekhawatiran utama (Rao, 2002).

Kepercayaan yang dimaksud dalam konteks e-commerce mencakup kepercayaan konsumen online dan harapan dari karakteristik penjual online terhadap merek (McKnight et al., 2002). Kepercayaan merek akan menentukan pembelian konsumen terhadap merek dan kepercayaan akan berpotensi menciptakan hubungan-hubungan yang bernilai tinggi (Kim et al., 2008). Kotler \& Amstong (2007: 112) menyatakan brand trust atau kepercayaan merk adalah kesediaan konsumen untuk mempercayai suatu merek dengan segala resikonya karena adanya harapan di benak mereka bahwa merek tersebut akan memberikan hasil yang positif kepada konsumen sehingga akan menimbulkan kesetiaan terhadap suatu merek.

Munculnya berbagai macam produk dalam satu kategori dengan kualitas produk yang sudah menjadi standar dan dapat dengan mudah ditiru dan dimiliki oleh siapapun megakibatkan sulitnya suatu perusahaan untuk mempertahankan dirinya sebagai pemimpin pasar (Heijden et al., 2003). Untuk mengatasi penetrasi yang dilakukan oleh kompetitor, maka perusahaan akan tetap menjaga pangsa pasarnya, salah satunya dengan membentuk citra merek yang kuat oleh perusahaan. Tanpa citra merek yang kuat dan positif, sangatlah sulit bagi perusahaan untuk menarik pelanggan baru dan mempertahankan kepercayaan merek (brand trust) konsumen (Delafrooz et al., 2011). Oleh karena itu dalam penelitian ini brand trust ditempatkan sebagai variabel independen yang menentukan nilai yang dirasakan pada produk di saat berbelanja online. 
Alshibly (2015), menyatakan setidaknya ada dua variabel yaitu kepercayaan merek dan kualitas layanan yang dapat mempengaruhi loyalitas pelanggan. Loyalitas pelanggan di persepsikan sebagai kunci penggerak untuk hubungan jangka panjang antara suplier atau perusahaan dengan pembeli yangterkait dengan kepercayaan konsumen terhadap merek dan kualitas layanan (Abdul and Asad-ur, 2014). Pentingnya loyalitas pelanggan bagi perusahaan sudah tidak diragukan lagi, banyak perusahaan sangat berharap dapat mempertahankan pelanggannya dalam jangka panjang, bahkan jika mungkin untuk selamanya (Mowen \& Minor, 2007:87). Perusahaan yang mampu mengembangkan dan mempertahankan loyalitas konsumen akan memperoleh kesuksesan jangka panjang (Kassim dan Abdullah, 2010).

Floh dan Treiblmaier (2006), meneliti faktor yang membuat loyalitas pelanggan terhadap suatu layanan internet banking, bahwa loyalitas pelanggan internet banking secara langsung dipengaruhi oleh kepercayaan atau trustyang berbasis web yang ditentukan oleh kualitas web dan kualitas layanan. Mowen \& Minor (2007:87) menyatakan bahwa salah satu kunci terbesar untuk meraih keberhasilan jangka panjang bisa disimpulkan dalam empat kata sederhana ini: pelayanan yang berkualitas terhadap pelanggan. Membangun loyalitas pelanggan bukanlah suatu hal yang mudah apalagi jika menghendaki hal tersebut berlangsung secara instant. Penilaian evaluatif pasca pemilihan yang disebabkan oleh seleksi pembelian khusus dan pengalaman menggunakan barang atau jasa tersebut. Loyalitas pelanggan merupakan sikap menyenangi terhadap suatu merek yang direpresentasikan dalam pembelian yang konsisten terhadap merek itu 
sepanjang waktu dengan nilai yang dirasakan pada suatu produk (Shahroudi et al., 2015).

Tujuan yang ingin dicapai melalui penelitian ini adalah untuk mengkaji pengaruh kepercayaan merek, kualitas layanan dan persepsi nilai pelanggan terhadap loyalitas pelanggan pada Zalora online shop, mengkaji pengaruh kepercayaan merek dan kualitas layanan terhadap persepsi nilai pelanggan pada Zalora online shop, serta untuk mengetahui persepsi nilai pelanggan memediasi kepercayaan merek dan kualitas layanan terhadap loyalitas pelanggan. Hasil penelitian ini diharapkan dapat memberikan manfaat bagi produsen Zalora online shop, dalam pengambilan kebijakan untuk menghasilkan variasi produk yang diminati oleh konsumen.

Alshibly (2015) menemukan brand trust pada suatu merek mampu memberikan dampak positif dan signifikan dalam menciptakan loyalitas pelanggan. Ini pun diungkapkan oleh Kassim (2010) brand trust mampu menciptakan dampak positif signifikan terhadap loyalitas pelanggan. Hal yang sama di buktikan oleh Shahroudi et al. (2015) brand trust memberikan pengaruh positif terhadap loyalitas pelanggan. Berdasarkan pemahaman tersebut dapat dirumuskan hipotesis pertama sebagai berikut.

$\mathrm{H}_{1}$ : kepercayaan merek mempengaruhi loyalitas pelanggan secara positif.

Loyalitas pelanggan akan terjadi dengan sendirinya apabila pelanggan merasakan kualitas layanan secara positif (Asim et al., 2012). Dewi et al. (2012) membuktikan bahwa kualitas layanan secara positif akan mewujudkan loyalitas pelanggan yang dimiliki konsumen akan suatu produk. Yen, 2013 (2013) 
Dicka Puspita Ayu, Persepsi Nilai Pelanggan Memediasi Pengaruh...

membuktikan kualitas layanan sebagai loyalty intention konsumen secara positif dapat mewujudkan loyalitas pelanggan. Berdasarkan hasil penelitian tersebut, diajukan hipotesis ke empat sebagai berikut.

$\mathrm{H}_{2}$ : kualitas layanan mempengaruhi loyalitas pelanggan secara positif.

Huang et al. (2011) mengamati bahwa kepercayaan konsumen akan suatu merek akan memberikan dampak positif pada persepsi nilai pelanggan secara keseluruhan. Kepercayaan mereka adalah perasaan aman yang dimiliki konsumen akibat dari interaksinya dengan sebuah merek, yang memberikan pengaruh positif pada persepsi nilai pelanggan bahwa merek tersebut dapat diandalkan dan bertanggung jawab atas kepentingan dan keselamatan dari konsumen (Qurat \& Mahira, 2011). Kepercayaan akan suatu merek secara logis akan memberikan pengaruh positif pada persepsi nilai konsumen (Beneke et al., 2011). Berdasarkan hasil penelitian tersebut, diajukan hipotesis ke empat sebagai berikut.

$\mathrm{H}_{3}$ :kepercayaan merek mempengaruhi persepsi nilai pelanggan secara positif.

Beneke et al. (2011) menyatakan kualitas layanan adalah perbandingan antara layanan yang diharapkan konsumen dengan layanan yang diterimanya. Kualitas layanan memiliki pengaruh positif pada persepsi nilai pelanggan (Kassim \& Abdullah, 2010). Menyatakan Kualitas layanan yang diberikan memiliki pengaruh positif pada persepsi nilai pelanggan. Kualitas layanan yang dirasakan konsumen akan memberikan dampak positif pada persepsi nilai pelanggan (Floh\& Treiblmaier, 2006). Berdasarkan hasil penelitian tersebut, diajukan hipotesis ke empat sebagai berikut.

$\mathrm{H}_{4}$ : kualitas layanan mempengaruhi persepsi nilai pelanggan secara positif 
Alshibly (2015) menyatakan persepsi nilai pelanggan adalah ikatan emosional yang terjalin antara pelanggan dan produsen setelah pelanggan menggunakan produk dan jasa dari perusahaan dan mendapati bahwa produk atau jasa tersebut memberi nilai tambah. Persepsi nilai pelanggan memiliki pengaruh positif yang akan menciptakan loyalitas pelanggan (Alshibly, 2015). Yen (2013) membuktikan bahwa persepsi nilai pelanggan memiliki pengaruh positif pada loyalitas pelanggan. Persepsi nilai yang dirasakan pelangganakan memberikan dampak positif pada loyalitas pelanggan (Kassim \& Abdullah, 2010). Berdasarkan hasil penelitian tersebut, diajukan hipotesis ke empat sebagai berikut.

$\mathrm{H}_{5}$ : persepsi nilai pelanggan mempengaruhi loyalitas pelanggan secara positif.

Alshibly (2015) mengamati bahwa persepsi kualitas, persepsi nilai pelanggan secara keseluruhan menunjukkan berperan dalam memediasi pengaruh kepercayaan merek dan kualitas layanan terhadap loyalitas pelanggan. Persepsi nilai pelanggan sebagai dukungan positif dalam menciptakan hubungan brand trust dan kualitas layanan terhadap loyalitas pelanggan (Beneke et al., 2011). Cronin et al. (2000), mengamati bahwa persepsi nilai pelanggan secara keseluruhan yang dirasakan konsumen semua diukur dalam arti global menunjukkan peran mediasi pengaruh kepercayaan merek dan kualitas layanan terhadap loyalitas pelanggan. Berdasarkan hasil penelitian tersebut, diajukan hipotesis ke empat sebagai berikut

$\mathrm{H}_{6}$ : persepsi nilai pelanggan memediasi pengaruh kepercayaan merek dan kualitas layanan dengan loyalitas pelanggan secara positif. 
Berdasarkan penjelasan sebelumnya, maka dapat diajukan model penelitian yang menggambarkan hubungan antar variabel pada Gambar 1 berikut.

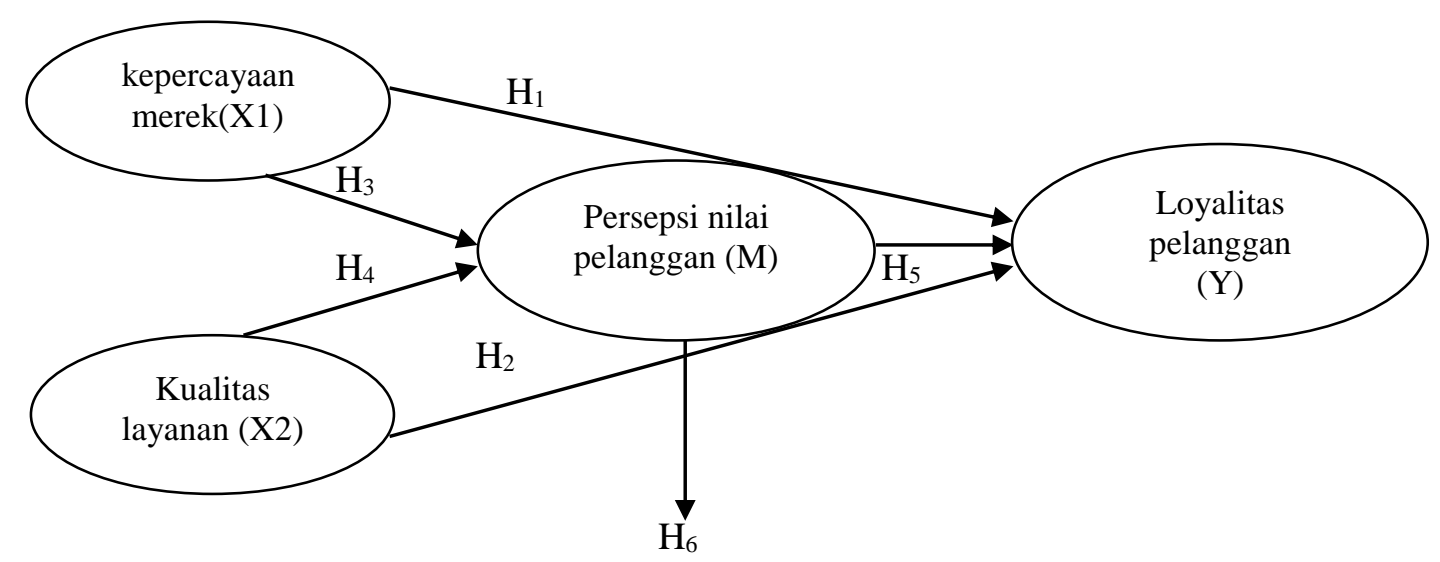

\section{Gambar 1 Model Kerangka Berfikir}

Sumber: Konsep yang dikembangkan dalam penelitian ini, 2017

\section{METODE PENELITIAN}

Penelitian ini termasuk jenis penelitian kausalitas yaitu penelitian yang bertujuan untuk menguji hubungan kausalitas antara variabel kepercayaan merk, kualitas layanan, nilai yang dirasakan (persepsi nilai pelanggan), dan loyalitas pelanggan.

Penelitian ini akan dilakukan dengan menjadikan sosial media Zalora Online shop sebagai lokasi penelitian, karena Zalora Online shop lebih mudah dan bisa diakses kapan saja, menyajikan informasi terbaru dan sudah dikenal oleh masyarakat jadi lebih dipercaya jika melakukan transaksi jual beli online.

Obyek dalam penelitian adalah peran persepsi nilai pelanggan memediasi pengaruh kepercayaan merek dan kualitas layanan terhadap loyalitas pelanggan berbelanja online (Studi kasus pada Zalora Online shop). Variabel yang digunakan dalam penelitian ini diuraikan dalam Tabel 1 berikut: 
Tabel 1.

Identifikasi Variabel

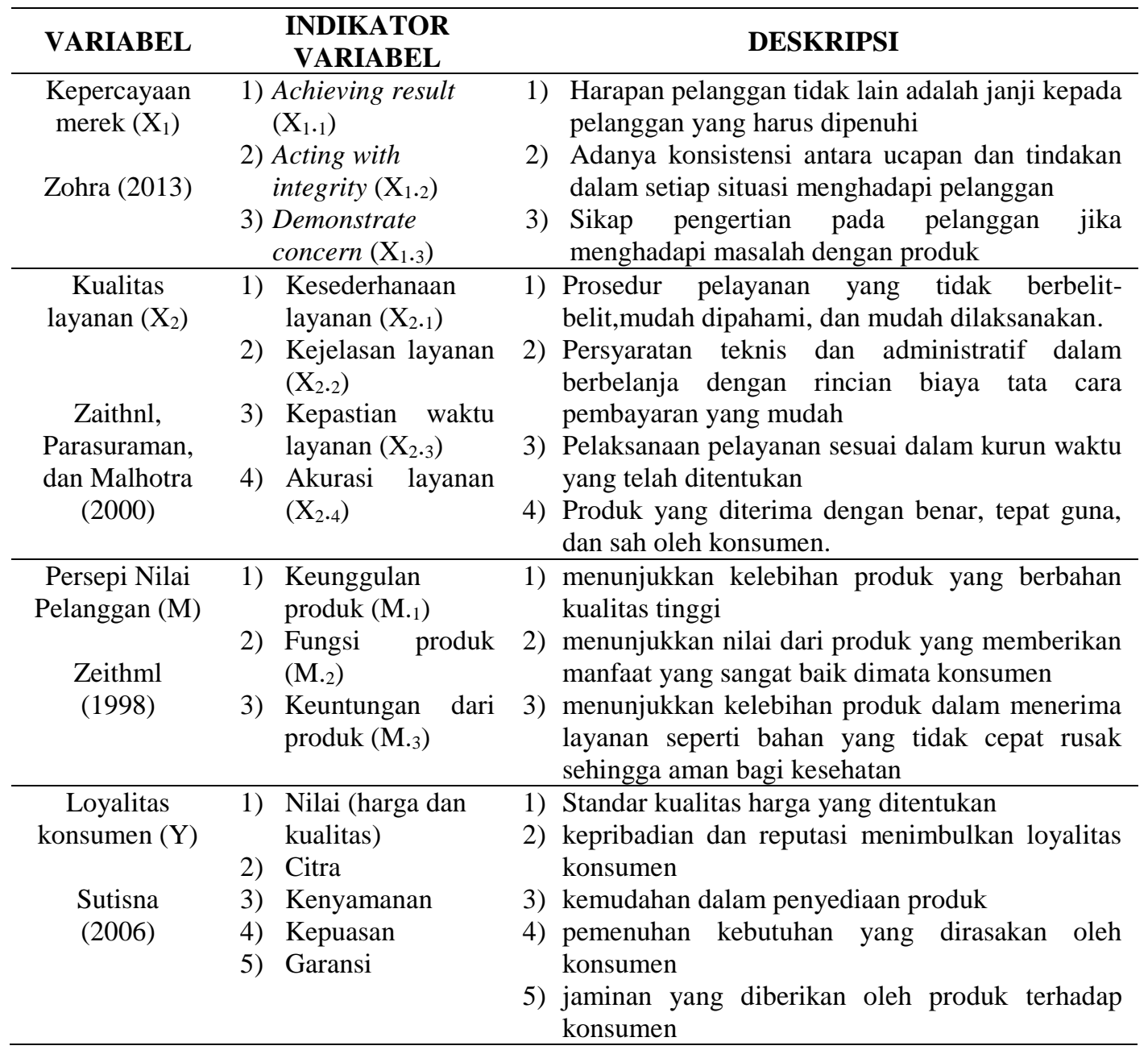

\section{HASIL DAN PEMBAHASAN}

Berdasarkan hasil penelitian, didapat sebuah gambaran tentang karakteristik responden yang menunjukkan bahwa berdasarkan pengelompokkan jenis kelamin, maka jenis kelamin perempuan mendominasi dalam penelitian ini dengan persentase sebesar 76,7 persen, hal ini disebabkan karena berbelanja online di Zalora online shop memberikan kemudahan dalam menemukan barang yang dibutuhkan untuk memenuhi fashion mereka yang membuat para wanita lebih elegan, modis sehingga jatuh hati untuk membelinya.Berdasarkan umur 
Dicka Puspita Ayu, Persepsi Nilai Pelanggan Memediasi Pengaruh...

responden di dominasi pada usia >17-35 tahun dengan persentase sebesar 63,4 persen. Persentase terkecil yaitu 17,3 persen dengan jumlah responden sebanyak 26 orang yang berumur 46-55 tahun. Hal ini berarti bahwa, masyarakat di media sosial yang melakukan pembelian produk di Zalora online shop rata-rata berumur >17-35 tahun di mana rentang usia ini termasuk rentak usia yang produktif dengan gaya hidup yang modern dan fashionnabel.

Tabel 2.

Karakteristik Responden

\begin{tabular}{ccccc}
\hline \multirow{2}{*}{ No } & \multirow{2}{*}{ Variabel } & Klasifikasi & $\begin{array}{c}\text { Jumlah } \\
\text { (orang) }\end{array}$ & Persentase \\
\hline 1 & Jenis & Laki - Laki & 35 & 23,3 \\
& Kelamin & Perempuan & 115 & 76,7 \\
& & Jumlah & 150 & 100 \\
\hline 2 & Umur & $17-35$ tahun & 95 & 63,4 \\
& $36-45$ tahun & 29 & 19,3 \\
& & $46-55$ tahun & 26 & 17,3 \\
& & 55 tahun & - & - \\
& & Jumlah & 150 & 100 \\
\hline 4 & Berbelaja & 3 Kali & 11 & 7,3 \\
& & 4 Kali & 89 & 59,3 \\
& & 5 Kali & 38 & 25,3 \\
& & $>5$ Kali & 12 & 8,1 \\
& & Jumlah & 150 & 100 \\
\hline 5 & Pendidikan & SLTP & 18 & 12 \\
& & SLTA & 24 & 16 \\
& & S.1 & 75 & 50 \\
& & S.2 & 33 & 22 \\
& & Jumlah & 150 & 100 \\
\hline
\end{tabular}

Sumber : Data Primer Diolah, 2017

Berdasarkan beberapa kali sudah berbelanja di Zalora online shop didominasi sebanyak 4 kali dengan persentase sebesar 59,3 persen. Persentase terkecil yaitu 7,3 persen dengan berbelanja sebanyak 3 kali. Hal ini berarti bahwa, masyarakat di media sosial yang berbelanja produk di Zalora online shop cukup sering melakukan pembelian mengingat apa yang dibutuhkan konsumen sebagian besar dijual oleh Zalora online shop. 
Berdasarkan pengelompokkan pendidikan terakhir, pendidikan terakhir S1 mendominasi dalam penelitian ini dengan jumlah responden sebanyak 75orang 50 persen dan persentase terkecil yaitu 12 persen dengan jumlah responden sebanyak 18 orang yang berpendidikan SLTP. Hal ini dikarenakan dalam kategori pendidikan, ini dianggap sudah memiliki penghasilan sendiri yang cukup untuk bergaya up to date untuk melakukan pembelian produk di Zalora online shop.

Sebuah instrumen dikatakan valid jika mampu mengukur apa yang seharusnya diukur, dan dapat mengungkap data dari variabel yang diteliti secara tepat. Syarat minimum untuk dianggap memenuhi syarat adalah kalau $r=0,3$ ". Jadi kalau korelasi antara butir skor dengan skor total kurang dari 0,3 maka butir dalam instrumen tersebut dinyatakan tidak valid. Hasil uji validitas dalam penelitian ini menunjukkan bahwa masih-masing indikator variabel memiliki nilai person correlation lebih besar dari 0,30 , maka ini berarti indikator/pertanyaan yang digunakan layak digunakan untuk mengukur apa yang seharusnya diukur, dan dapat mengungkap data dari variabel yang diteliti secara tepat. Hasil penelitian juga menjelaskan bahwa nilai Cronbach's Alpha untuk masing-masing variabel > 0,6, ini berarti alat ukur tersebut akan memberikan hasil yang konsisten apabila alat ukur tesebut digunakan kembali untuk meneliti obyek yang sama.

Hasil analisis deskriptif disajikan untuk memberikan informasi mengenai distribusi variabel-variabel penelitian. Distribusi penilaian responden di Kota Denpasar, mengenai kepercayaan merek $\left(\mathrm{X}_{1}\right)$ dapat dilihat pada Tabel 3 berikut. 
Tabel 3.

Hasil Penilaian Responden atas Variabel Kepercayaan Merek

\begin{tabular}{|c|c|c|c|c|c|c|c|c|c|}
\hline \multirow{2}{*}{ No } & \multirow{2}{*}{ Pernyataan } & \multicolumn{5}{|c|}{ Jawaban } & \multirow{2}{*}{$\begin{array}{l}\text { Total } \\
\text { Skor }\end{array}$} & \multirow{2}{*}{$\begin{array}{c}\text { Rata-rata } \\
\text { Skor }\end{array}$} & \multirow{2}{*}{$\begin{array}{l}\text { Kategori } \\
\text { Penilaian }\end{array}$} \\
\hline & & STB & TB & $\mathrm{C}$ & $\mathrm{B}$ & SB & & & \\
\hline 1 & $\begin{array}{l}\text { Harapan pelanggan } \\
\text { yang harus dipenuhi } \\
\text { Zalora }\end{array}$ & 3 & 13 & 48 & 50 & 36 & 553 & 3,69 & Baik \\
\hline 2 & $\begin{array}{l}\text { Zalora bertindak } \\
\text { dengan integritas, } \\
\text { adanya konsistensi } \\
\text { antara ucapan dan } \\
\text { tindakan }\end{array}$ & 0 & 22 & 39 & 54 & 35 & 552 & 3,68 & Baik \\
\hline 3 & $\begin{array}{l}\text { Perhatian Zalora } \\
\text { kepada pelanggan } \\
\text { dalam bentuk } \\
\text { menunjukkan sikap } \\
\text { pengertian kepada } \\
\text { pelanggan }\end{array}$ & 0 & 23 & 49 & 27 & 51 & 556 & 3,71 & Baik \\
\hline \multicolumn{7}{|c|}{ Jumlah } & 1661 & 11,08 & Baik \\
\hline \multicolumn{7}{|c|}{ Rata-rata skor } & 553,6 & 3,69 & \\
\hline
\end{tabular}

Sumber: Data Primer Diolah, 2017

Tabel 3 menjelaskan persepsi responden mengenai variabel kepercayaan merek dapat dilihat secara keseluruhan memiliki nilai total rata-rata jawaban responden sebesar 3,69 yang masuk dalam kategori baik. Pernyataan ketiga yaitu "perhatian Zalora kepada pelanggan dalam bentuk menunjukkan sikap pengertian kepada pelanggan jika menghadapi masalah dengan produk" dengan skor nilai jawaban tertinggi sebesar 3,71 dan skor terendah sebesar 3,68 berada pada pernyataan ke dua yaitu "Zalora bertindak dengan integritas, adanya konsistensi antara ucapan dan tindakan dalam setiap situasi”. Maka dari itu Zalora online shop sebagai produsen produk harus bertindak dengan integritas, melalui konsistensi dalam melaksanakan pemasaran antara ucapan dan tindakan dalam setiap situasi sehingga pandangan konsumen berbelanja di Zalora online shop sangat berguna sehingga menjadi inspirasi dan meningkatkan loyalitas pelanggan berbelanja online. 
Rekapitulasi penilaian responden di Kota Denpasar, mengenai kualitas layanan $\left(\mathrm{X}_{2}\right)$ dapat dilihat pada Tabel 4 sebagai berikut.

Tabel 4.

\section{Hasil Penilaian Responden atas Variabel Kualitas Layanan}

\begin{tabular}{|c|c|c|c|c|c|c|c|c|c|}
\hline \multirow{2}{*}{ No } & \multirow{2}{*}{ Pernyataan } & \multicolumn{5}{|c|}{ Jawaban } & \multirow{2}{*}{$\begin{array}{l}\text { Total } \\
\text { Skor }\end{array}$} & \multirow{2}{*}{$\begin{array}{c}\text { Rata-rata } \\
\text { Skor }\end{array}$} & \multirow{2}{*}{$\begin{array}{l}\text { Kategori } \\
\text { Penilaian }\end{array}$} \\
\hline & & STB & TB & $\mathrm{C}$ & B & SB & & & \\
\hline 1 & $\begin{array}{l}\text { Zalora memberikan } \\
\text { prosedur pelayanan } \\
\text { yang tidak berbelit- } \\
\text { belit, mudah } \\
\text { dipahami, dan mudah } \\
\text { dilaksanakan. }\end{array}$ & 7 & 21 & 58 & 43 & 21 & 500 & 3,33 & Baik \\
\hline 2 & $\begin{array}{l}\text { Zalora memberikan } \\
\text { kejelasan, meliputi } \\
\text { persyaratan teknis } \\
\text { dan administratif } \\
\text { dalam berbelanja } \\
\text { dengan rincian biaya } \\
\text { tata cara pembayaran. }\end{array}$ & 0 & 17 & 32 & 50 & 51 & 585 & 3,90 & Baik \\
\hline 3 & $\begin{array}{l}\text { Zalora memberikan } \\
\text { kepastian waktu } \\
\text { adalah pelaksanaan } \\
\text { pelayanan dalam } \\
\text { kurun waktu yang } \\
\text { telah ditentukan. }\end{array}$ & 1 & 21 & 51 & 45 & 32 & 536 & 3,57 & Baik \\
\hline 4 & $\begin{array}{l}\text { Produk zalora dapat } \\
\text { diterima dengan } \\
\text { benar, tepat, dan sah } \\
\text { oleh konsumen. }\end{array}$ & 0 & 19 & 49 & 45 & 37 & 550 & 3,67 & Baik \\
\hline \multicolumn{7}{|c|}{$\begin{array}{l}\text { Jumlah } \\
\end{array}$} & 2171 & 14,47 & Baik \\
\hline \multicolumn{7}{|c|}{ Rata-rata skor } & 543 & 3,62 & \\
\hline
\end{tabular}

Sumber: Data Primer Diolah, 2017

Tabel 4 menjelaskan persepsi responden mengenai variabel kualitas layanandapat dilihat secara keseluruhan memiliki nilai total rata-rata jawaban responden sebesar 3,62 yang masuk dalam kategori baik. Pernyataan kedua yaitu "Zalora memberikan kejelasan, meliputi persyaratan teknis dan administratif dalam berbelanja dengan rincian biaya tata cara pembayaran" memiliki skor nilai jawaban tertinggi sebesar 3,90 dan skor terendah sebesar 3,33 berada pada pernyataan pertama "Zalora memberikan prosedur pelayanan yang tidak berbelit- 
Dicka Puspita Ayu, Persepsi Nilai Pelanggan Memediasi Pengaruh...

belit, mudah dipahami, dan mudah dilaksanakan”. Maka dari itu Zalora online shop sebagai produsen harus memberikan pelayanan yang mengutamakan kecepatan, dari segi transaksi, pembayaran yang mengesankan tidak berbelit-belit, mudah dipahami, dan mudah dilaksanakan oleh konsumen sehingga konsumen memiliki loyalitas untuk berbelanja di Zalora online shop.

Rekapitulasi penilaian responden di media sosial, mengenai persepsi nilai pelanggan (M) dapat dilihat pada Tabel 5 sebagai berikut.

Tabel 5.

Hasil Penilaian Responden atas Variabel Persepsi Nilai Pelanggan

\begin{tabular}{|c|c|c|c|c|c|c|c|c|c|}
\hline \multirow[t]{2}{*}{ No } & \multirow[t]{2}{*}{ Pernyataan } & \multicolumn{5}{|c|}{ Jawaban } & \multirow{2}{*}{$\begin{array}{l}\text { Total } \\
\text { Skor }\end{array}$} & \multirow{2}{*}{$\begin{array}{c}\text { Rata-rata } \\
\text { Skor }\end{array}$} & \multirow{2}{*}{$\begin{array}{l}\text { Kategori } \\
\text { Penilaian }\end{array}$} \\
\hline & & STB & TB & $\mathrm{C}$ & B & SB & & & \\
\hline 1 & $\begin{array}{l}\text { Keunggulan produk zalora } \\
\text { yang berbahan dengan } \\
\text { kualitas terbaik. }\end{array}$ & 11 & 20 & 44 & 49 & 26 & 509 & 3,39 & Baik \\
\hline 2 & $\begin{array}{l}\text { Fungsi produk zalora yang } \\
\text { menunjukkan nilai dari } \\
\text { produk yang memberikan } \\
\text { manfaat yang sangat baik } \\
\text { dimata konsumen. }\end{array}$ & 2 & 20 & 39 & 47 & 42 & 557 & 3,71 & Baik \\
\hline 3 & $\begin{array}{l}\text { Keuntungan dari produk } \\
\text { zalora menunjukkan } \\
\text { kelebihan dalam menerima } \\
\text { layanan seperti bahan yang } \\
\text { tidak cepat rusak sehingga } \\
\text { aman bagi kesehatan }\end{array}$ & 11 & 22 & 37 & 44 & 36 & 522 & 3,48 & Baik \\
\hline \multicolumn{7}{|c|}{ Jumlah } & 1588 & $\mathbf{1 0 , 5 8}$ & Baik \\
\hline \multicolumn{7}{|c|}{ Rata-rata skor } & 529,3 & 3,53 & \\
\hline
\end{tabular}

Sumber: Data Primer Diolah, 2017

Tabel 5 menjelaskan persepsi responden mengenai variabel persepsi nilai pelanggandapat dilihat secara keseluruhan memiliki nilai total rata-rata jawaban responden sebesar 3,53yang masuk dalam kategori baik. Pernyataan kedua yaitu "fungsi produk zalora yang menunjukkan nilai dari produk yang memberikan manfaat yang sangat baik dimata konsumen" dengan skor nilai jawaban tertinggi sebesar 3,71 dan skor terendah sebesar 3,39 berada pada pernyataan pertama yaitu 
"keunggulan produk zalora yang berbahan dengan kualitas terbaik". Maka dari itu Zalora online shop sebagai produsen harus mempertahankan nama baik dalam segi kualitas produk melalui bahan terpercaya, terbaik sehingga konsumen merasa nyaman dan bahagi jika melakukan pembelian di Zalora online shop.

Rekapitulasi penilaian responden di Kota Denpasar, mengenai loyalitas pelanggan (Y) dapat dilihat pada Tabel 6 sebagai berikut.

Tabel 6.

Hasil Penilaian Responden atas Variabel Loyalitas Pelanggan

\begin{tabular}{|c|c|c|c|c|c|c|c|c|c|}
\hline \multirow{2}{*}{ No } & \multirow{2}{*}{ Pernyataan } & \multicolumn{5}{|c|}{ Jawaban } & \multirow{2}{*}{$\begin{array}{l}\text { Total } \\
\text { Skor }\end{array}$} & \multirow{2}{*}{$\begin{array}{c}\text { Rata-rata } \\
\text { Skor }\end{array}$} & \multirow{2}{*}{$\begin{array}{l}\text { Kategori } \\
\text { Penilaian }\end{array}$} \\
\hline & & STB & TB & $\mathrm{C}$ & $\mathrm{B}$ & SB & & & \\
\hline 1 & $\begin{array}{l}\text { Saya membeli produk } \\
\text { Zalora dengan standar } \\
\text { kualitas harga yang } \\
\text { ditentukan. }\end{array}$ & 0 & 17 & 43 & 48 & 42 & 565 & 3,77 & Baik \\
\hline 2 & $\begin{array}{l}\text { Saya tetap } \\
\text { membeliproduk Zalora } \\
\text { dengan reputasinya }\end{array}$ & 0 & 20 & 61 & 40 & 29 & 528 & 3,52 & Baik \\
\hline 3 & $\begin{array}{l}\text { Saya tetap } \\
\text { membeliproduk Zalora } \\
\text { dengan } \\
\text { kemudahannya. }\end{array}$ & 3 & 30 & 40 & 41 & 36 & 527 & 3,51 & Baik \\
\hline 4 & $\begin{array}{l}\text { Saya tetap } \\
\text { membeliproduk Zalora } \\
\text { untuk pemenuhan } \\
\text { kebutuhan saat ini. }\end{array}$ & 0 & 28 & 45 & 46 & 31 & 530 & 3,53 & Baik \\
\hline 5 & $\begin{array}{l}\text { Saya membeliproduk } \\
\text { Zalora karena } \\
\text { diberikan garansi }\end{array}$ & 2 & 25 & 43 & 52 & 28 & 529 & 3,53 & Baik \\
\hline \multicolumn{7}{|c|}{ Jumlah } & $\begin{array}{c}2679 \\
536 \\
\end{array}$ & $\begin{array}{c}17,86 \\
3,57 \\
\end{array}$ & Baik \\
\hline
\end{tabular}

Sumber: Data Primer Diolah, 2017

Tabel 6 menjelaskan persepsi responden mengenai variabel loyalitas pelanggan dapat dilihat secara keseluruhan memiliki nilai total rata-rata jawaban responden sebesar 3,57 yang masuk dalam kategori baik. Pernyataan pertama yaitu "saya tetap membeli produk Zalora Online shop dengan standar kualitas harga yang ditentukan" dengan skor nilai jawaban tertinggi sebesar 3,71 dan skor terendah sebesar 3,51 berada pada pernyataan ke tiga yaitu "saya tetap membeli 
produk Zalora Online shop dengan kemudahan memperolehnya". Maka dari itu Zalora online shopsebagai produsen harusselalu memberikan kemudahan kepada konsumen yang ingin berbelanja dengan menyediakan produk unggulan, up to date yang berkesan glamour dimata konsumen sehingga konsumen merasa mudah menemukannya apabila berbelanja di Zalora online shop.

Pengujian data penelitian ini menggunakan teknik analisis jalur (Path Analysis) dengan model diagram jalur seperti pada Gambar 2 berikut.

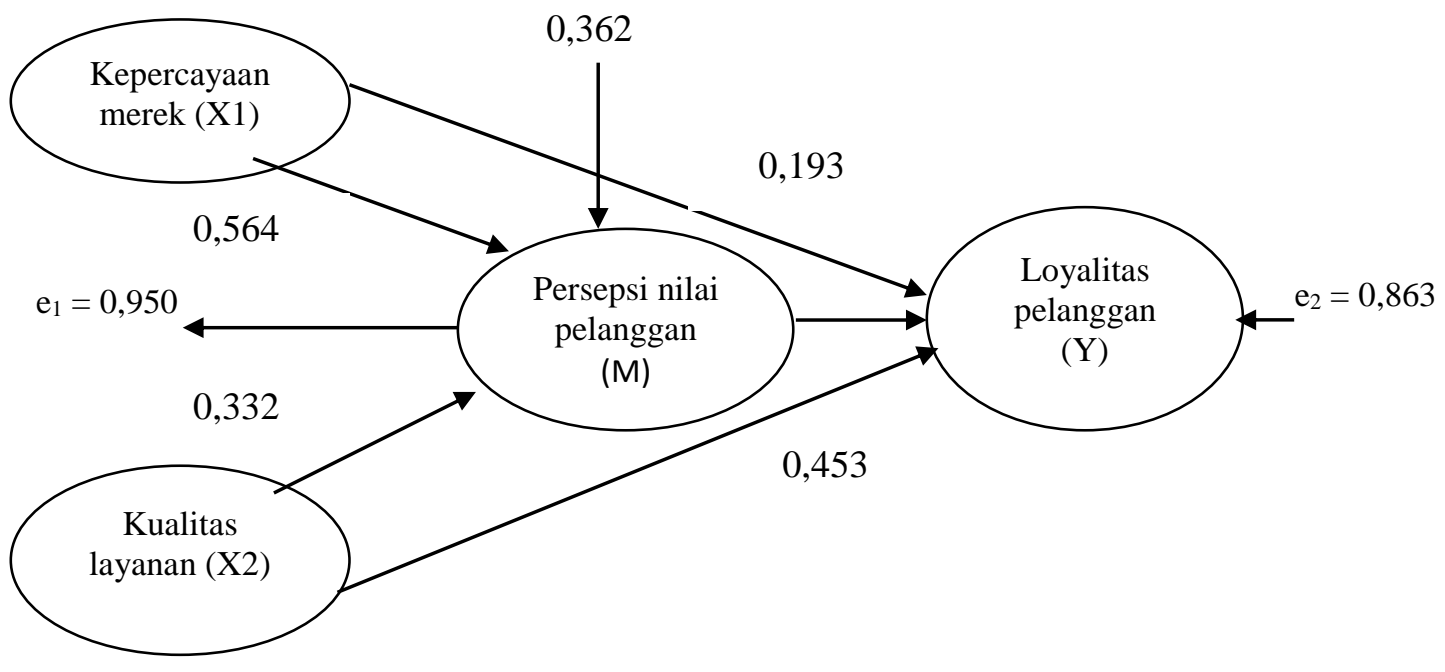

Sumber: Data Primer Diolah, 2017

\section{Gambar 2. Model Jalur Persepsi Nilai Pelanggan Memediasi Kepercayaan Merek dan Kualitas Layanan Pada Loyalitas Pelanggan}

Gambar 2 menunjukkan nilai koefisien jalur pada model pengaruh kepercayaan merek dan kualitas layanan terhadap loyalitas pelanggan dengan mediasi persepsi nilai pelanggan. Berdasarkan informasi pada Gambar 4.1 diketahui bahwa koefisien jalur pengaruh kepercayaan merk dan kualitas layanan terhadap loyalitas pelanggan setelah variabel persepsi nilai pelanggan dimasukan ke dalam model bernilai 0,362 tidak bernilai 0 , yang berarti persepsi nilai 
pelanggan memediasi pengaruh positif kepercayaan merek dan kualitas layanan terhada ployalitas pelanggan berbelanja online di Zalora Online shop.

Nilai determinasi total dalam penelitian ini diperoleh sebesar 0,329 mempunyai arti bahwa sebesar 32,9\% variasi loyalitas pelanggan dipengaruhi oleh variabel kepercayaan merek dan kualitas layanan yang dimediasi oleh persepsi nilai pelanggan, sedangkan sisanya sebesar 67,1 persen dijelaskan oleh faktor lain yang tidak dimasukkan ke dalam model.

Berdasarkan hasil dari koefisien jalur pada hipotesis penelitian, maka dapat digambarkan hubungan kausal antar variabel persepsi nilai pelanggan memediasi pengaruh kepercayaan merk dan kualitas layanan terhadap loyalitas pelanggan. Perhitungan pengaruh antar variabel dirangkum dalam Tabel 7 berikut.

Tabel 7.

Pengaruh Langsung dan Pengaruh Tidak Langsung Serta Pengaruh Total Variabel Penelitian

\begin{tabular}{llccc}
\hline Pengaruh Variabel & $\begin{array}{c}\text { Pengaruh } \\
\text { Langsung }\end{array}$ & $\begin{array}{c}\text { Pengaruh Tidak } \\
\text { Langsung M } \\
(\mathbf{p 1 ~ x ~ p 3 ) ~}\end{array}$ & Pengaruh Total \\
\hline $\mathrm{P} 1$ & $\mathrm{X}_{1} \rightarrow \mathrm{Y}$ & 0,193 & - & 0,193 \\
\hline $\mathrm{P} 2$ & $\mathrm{X}_{2} \rightarrow \mathrm{Y}$ & 0,453 & - & 0,453 \\
\hline $\mathrm{P} 3$ & $\mathrm{X}_{1} \rightarrow \mathrm{M}$ & 0,564 & - & 0,564 \\
\hline $\mathrm{P} 4$ & $\mathrm{X}_{2} \rightarrow \mathrm{M}$ & 0,332 & - & 0,332 \\
\hline $\mathrm{P} 5$ & $\mathrm{M} \rightarrow \mathrm{Y}$ & 0,362 & - & 0,362 \\
\hline $\mathrm{P} 6$ & $\mathrm{X}_{1}, \mathrm{X}_{2} \rightarrow \mathrm{M} \rightarrow \mathrm{Y}$ & 0,362 & 0,108 & 0,470 \\
\hline
\end{tabular}

Sumber: Data Primer Diolah, 2017

Hasil uji parsial menunjukan bahwa kepercayaan merk berpengaruh positif dan signifikan terhada ployalitas pelanggan berbelanja di Zalora Online shop. Kepercayaan akan suatu merek bagi konsumen akan mampu memberikan dampak positif dan signifikan dalam menciptakan loyalitas pelanggan. Hasil penelitian ini sesuai dengan penelitian Alshibly (2015) menemukan kepercayaan merek pada 
Dicka Puspita Ayu, Persepsi Nilai Pelanggan Memediasi Pengaruh...

suatu merek mampu memberikan dampak positif dan signifikan dalam menciptakan loyalitas pelanggan. Ini pun diungkapkan oleh Kassim (2010) kepercayaan merek mampu menciptakan dampak positif signifikan terhadap loyalitas pelanggan. Hal yang sama di buktikan oleh Shahroudi et al.(2015) kepercayaan merek memberikan pengaruh positif terhadap loyalitas pelanggan.

Hasil uji parsial menunjukan bahwa kualitas layanan berpengaruh positif dan signifikan terhadap loyalitas pelanggan berbelanja di Zalora Online shop. Kualitas layanan akan memberikan peran positif terhadap loyalitas pelanggan dalam berbelanja online. Hasil penelitian ini sesuai dengan penelitian Asim et al. (2012) loyalitas pelanggan akan terjadi dengan sendirinya apabila pelanggan merasakan kualitas layanan secara positif. Dewi et al. (2012) membuktikan bahwa kualitas layanan secara positifakan mewujudkan loyalitas pelanggan yang dimiliki konsumen akan suatu produk. Yen, 2013 (2013) membuktikan kualitas layanan sebagai loyalty intention konsumen secara positif dapat mewujudkan loyalitas pelanggan.

Hasil uji parsial menunjukan bahwa kepercayaan merek berpengaruh positif dan signifikan terhada ppersepsi nilai pelanggan berbelanja di Zalora Online shop. Kepercayaan merk secara langsung akan memberikan peran positif pada persepsi nilai pelanggan secara keseluruhan. Hasil penelitian ini sesuai dengan penelitian Huang et al.(2011) mengamati bahwa kepercayaan konsumen akan suatu merk akan memberikan dampak positif pada persepsi nilai pelanggansecara keseluruhan.Kepercayaan mereka adalah perasaan aman yang dimiliki konsumen akibat dari interaksinya dengan sebuah merek, yang memberikan pengaruh positif 
pada persepsi nilai pelanggan bahwa merek tersebut dapat diandalkan dan bertanggung jawab atas kepentingan dan keselamatan dari konsumen (Qurat \& Mahira, 2011). Kepercayaan akan suatu merk secara logis akan memberikan pengaruh positif pada persepsi nilai konsumen (Beneke et al., 2011).

Hasil uji parsial menunjukan bahwa kualitas layanan berpengaruh positif dan signifikan terhadap persepsi nilai pelanggan berbelanja di Zalora Online shop. Kualitas layanan yang diberikan oleh Zalora Online shop akan memberikan pengaruh positif pada persepsi nilai pelanggan. Hasil penelitian ini sesuai dengan penelitian Beneke et al. (2011) menyatakan kualitas layanan adalah perbandingan antara layanan yang diharapkan konsumen dengan layanan yang diterimanya. Kualitas layanan memiliki pengaruh positif pada persepsi nilai pelanggan (Kassim\& Abdullah, 2010).Menyatakan Kualitas layanan yang diberikan memiliki pengaruh positif pada persepsi nilai pelanggan. Kualitas layanan yang dirasakan konsumen akan memberikan dampak positif pada persepsi nilai pelanggan (Floh\& Treiblmaier, 2006).

Hasil uji parsial menunjukan bahwapersepsi nilai pelanggan berpengaruh positif dan signifikan terhadap loyalitas pelanggan berbelanja di Zalora Online shop. Persepsi nilai pelanggan mencakup pada penilaian konsumen terhadap produk akan meningkatkan loyalitas pelanggan berbelanja di Zalora Online shop. Hasil penelitian ini sesuai dengan penelitian Alshibly (2015) menyatakan persepsi nilai pelanggan adalah ikatan emosional yang terjalin antara pelanggan dan produsen setelah pelanggan menggunakan produk dan jasa dari perusahaan dan mendapati bahwa produk atau jasa tersebut memberi nilai tambah. Persepsi nilai 
pelanggan memiliki pengaruh positif yang akan menciptakan loyalitas pelanggan (Alshibly, 2015). Yen (2013) membuktikan bahwa persepsi nilai pelanggan memiliki pengaruh positif pada loyalitas pelanggan.

Hasil uji parsial menunjukan bahwa persepsi nilai pelanggan mampu memediasi pengaruh positif dan signifikan kepercayaan merek dan kualitas layanan terhadap loyalitas pelanggan berbelanja di Zalora Online shop. Kepercayaan merek dan kualitas layanan memiliki pengaruh positif pada loyalitas pelanggan berbelanja melalui peran nilai pelanggan terhadap produk di Zalora Online shop. Hasil penelitian ini sesuai dengan penelitian Alshibly (2015) mengamati bahwa persepsi nilai pelanggan secara keseluruhan menunjukkan berperan dalam memediasi pengaruh kepercayaan merkdan kualitas layanan terhadap loyalitas pelanggan.Persepsi nilai pelanggan sebagai dukungan positif dalam menciptakan hubungan kepercayaan merkdan kualitas layanan terhadap loyalitas pelanggan (Beneke et al., 2011). Cronin et al. (2000), mengamati bahwa persepsi nilai pelanggan secara keseluruhan yang dirasakan konsumen semua diukur dalam arti global menunjukkan peran mediasi pengaruh kepercayaan merek dan kualitas layanan terhadap loyalitas pelanggan.

\section{SIMPULAN DAN SARAN}

Simpulan yang dapat diambil berdasarkan hasil analisis dan pembahasan adalah kepercayaan merek berpengaruh signifikan terhadap loyalitas pelanggan berbelanja di Zalora Online shop. Kualitas layanan berpengaruh signifikan terhadap loyalitas pelanggan berbelanja di Zalora Online shop. Kepercayaan 
merek berpengaruh signifikan terhadap persepsi nilai pelanggan berbelanja di Zalora Online shop. Kualitas layanan berpengaruh signifikan terhadap persepsi nilai pelanggan berbelanja di Zalora Online shop. Persepsi nilai pelanggan berpengaruh signifikan terhadap loyalitas pelanggan berbelanja di Zalora Online shop. Persepsi nilai pelanggan memediasi secara parsia pengaruh kepercayaan merek dan kualitas layanan terhadap loyalitas pelanggan berbelanja di Zalora Online shop.

Berdasarkan hasil penelitian, maka saran yang dapat diberikan yaitu Zalora Online shop sebagai produsen penjualan produk harus bertindak dengan integritas, melalui konsistensi dalam melaksanakan pemasaran antara ucapan dan tindakan dalam setiap situasi sehingga pandangan konsumen berbelanja di Zalora online shop sangat berguna sehingga menjadi inspirasi dan meningkatkan loyalitas pelanggan berbelanja online.

Zalora online shop sebagai produsen harus memberikan pelayanan yang mengutamakan kecepatan, dari segi transaksi, pembayaran yang mengesankan tidak berbelit-belit, mudah dipahami, dan mudah dilaksanakan oleh konsumen sehingga konsumen memiliki loyalitas untuk berbelanja di Zalora online shop.

Zalora online shop sebagai produsen harus mempertahankan nama baik dalam segi kualitas produk melalui bahan terpercaya, terbaik sehingga konsumen merasa nyaman dan bahagi jika melakukan pembelian di Zalora online shop yang dengan sendirinya akan meningkatkan loyalitas pelanggan berbelanja online. 


\section{REFERENSI}

Abdul Ghafoor Awan and Asad-ur Rehman. 2014. Impact of customer satisfaction on brand loyalty an empirical analysis of home appliances in Pakistan. British Journal of Marketing Studies. Vol. 2, No. 8, Pp: 18-32

Alshibly, H. H. 2015. Customer perceived value in Social Commerce: An Exploration of Its Antecedents and Consequences. Journal of Management Research, Vol. 7, No. 1, Pp: 17-37.

Arnold, Mark J. and Reynolds, Kristy E. 2003. Hedonic shopping motivations. Journal of Retailing. Vol. 79. No.7, Pp:70-75.

Beneke, J., Adams, E., Demetriou, O., Solomons, R. 2011. An exploratory study of the relationship between store image, trust, satisfaction and loyalty in a franchise setting. Southern African Business Review. Vol. 15, No. 2, pp: 59-74.

Brandy, K. Michael; Cronin, J. Joseph and Richard, Brand R. 2001. Performanceonly measurement of service quality: a replication and extension. Journal of Business Research. Vol. 55, No. 1, pp: 17-31.

Cronin Jr, J. J., Brady, M. K., \& Hult, G. T. M. 2000. Assessing the effects of quality, value, and customer satisfaction on consumer behavioral intentions in service environments. Journal of retailing, Vol. 76, No. 2, Pp: 193-218

Dewi Renny Sari, A. Holil Noor Ali, dan Hanim Maria Astuti. 2012. Analisis Pengaruh Kualitas Informasi pada Kuesioner Indeks Pengajaran Dosen Online terhadap Kepuasan Pengguna Studi Kasus: Fakultas Teknologi Informasi ITS. E-Jurnal Institut Teknologi Sepuluh November, Vol. 1, No. 1, Hal: 345-351

Edwi Arief Sosiawan, 2011. Pengguna situs jejaring sosial sebagai media interaksi dan komunikasi di kalangan mahasiswa. Jurnal Ilmu Komunikasi, Vol. 9, No. 1, Hal : 60-75

Floh, A. and H. Treiblmaier. 2006. What Keeps The E-Banking Customer Loyal? A Multigroup Analysis of The Moderating Role of Consumer Characteristics on E-Loyalty in The Finansial Service Industry, Journal of Electronic Commerce Research, Vol. 7, No. 2. Pp: 97-110.

Fornell, C., Johnson, M. D., Anderson, E. W., Cha, J., \& Bryant, B. E. 1996. The American customer satisfaction index: nature, purpose, and findings. The Journal of Marketing, Vol. 60, No. 4. Pp: 7-18.

Heijden, H. van der. 2003. Factors influencing the usage of websites: the case of a generic Portal in the Netherlands. The Journal of Information \& Management Vol. 40, No. 6. Pp: 541-549 
Huang, Kineta., Li, Stella Yiyan; Tse, David K. 2011. Interpersonal Trust And Platform Credibility In A Chinese Multi Brand Online Community: Effects on Brand Variety Seeking and Time Spent". Journal of Advertising. Vol. 40, No. 3. Pp: 99-112.

Kim, S., \& Park, H. 2013. Effects of Various Characteristics of Social Commerce (s-commerce) on Consumers' Trust and Trust Performance. International Journal of Information Management, Vol. 33, No. 2, pp: 318-332

Kotler, Philip \& Kevin Lane. 2008. Manajemen Pemasaran. Jilid I. Edisi 12 Jakarta : Erlangga.

Kotler, Philip \& Keller. 2012. Manajemen Pemasaran. Edisi 12. Jilid 1. Alih Bahasa: Benyamin Molan. Jakarta: Indeks.

Mowen, J. dan Minor, M. 2007. Perilaku Konsumen. Jakarta: Erlangga

Parasuraman, A.; Zeithaml, Valeric A.; dan Berry, Leonard L. 1988. SERVQUAL: A Multiple-item Scale for Measuring Consumer Perceptions of Service Quality. Journal of Retailing. Vol. 64 No. 1, pp: 12-40.

Shahroudi, Kambiz and Naimi, Seyedeh Safoura. 2015. The Impact of Brand Image on Customer Satisfaction and Loyalty Intention (Case Study: Consumer of Hygiene Products). International Journal of Engineering Innovation \& Research. Vol. 3, No. 1. Pp: 57-61

Turley, L.W. and Milliman, Ronald E. 2000. Atmospheric Effects on Shopping Behavior. Journal of Business Research. Vol. 49, No.2, Pp: 193-211.

Xia, Lan. 2010. An examination of consumer browsing behaviors. International Journal. Vol. 13, No.2, Pp: 155-165

Zohra Sabunwala, 2013. Impact of Celebrity Brand Endorsement on Brand Image and Product Purchases-A Study for Pune Region of India. International Journal of Research in Business Management. Vol. 1, No.6, Pp: 37-42 